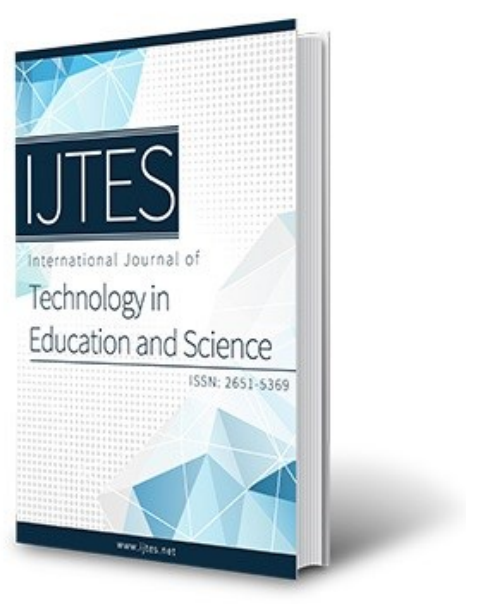

\title{
Lessons Learned from Teaching English through Facebook Live for Future
}

\author{
Prakash Chandra Giri (iD) \\ Nepal Open University, Nepal \\ Karna Rana \\ Nepal Open University, Nepal
}

www.ijtes.net

\section{To cite this article:}

Giri, P. C. \& Rana, K. (2022). Lessons learned from teaching English through Facebook live for future. International Journal of Technology in Education and Science (IJTES), 6(1), 1431. https://doi.org/10.46328/ijtes.309

The International Journal of Technology in Education and Science (IJTES) is a peer-reviewed scholarly online journal. This article may be used for research, teaching, and private study purposes. Authors alone are responsible for the contents of their articles. The journal owns the copyright of the articles. The publisher shall not be liable for any loss, actions, claims, proceedings, demand, or costs or damages whatsoever or howsoever caused arising directly or indirectly in connection with or arising out of the use of the research material. All authors are requested to disclose any actual or potential conflict of interest including any financial, personal or other relationships with other people or organizations regarding the submitted work. 


\title{
Lessons Learned from Teaching English through Facebook Live for Future
}

\author{
Prakash Chandra Giri, Karna Rana
}

\begin{tabular}{ll}
\hline Article Info & Abstract \\
\cline { 3 - 3 } $\begin{array}{l}\text { Article History } \\
\text { Received: }\end{array}$ Facebook Live has become a means of teaching and learning in many parts of the \\
Accepted: & world. This paper, thus, reports an examination of teaching English through \\
28 December 2021 & Facebook Live and students' experiences of learning on it in the COVID-19 \\
& pandemic. It as participatory action research employed observation of self- \\
& managed Facebook Live streaming, and an online semi-structured interview with \\
& students and parents. The intervention of Facebook Live consisted of three \\
& strategies: pre-recorded video streaming, live teaching and a combination of \\
Keywords & both. This paper reports on how students in absence of a physical classroom \\
English communication & learned English through Facebook Live, developed communicative skills and \\
Parental support & gacebook Live \\
COVID-19 crisis & appreciated by students and parents as students could get ideas for speaking \\
& English, students expressed concerns if they could interact with the teacher and \\
friends. Facebook Live associated with videoconferencing tools, however, can & complement physical classroom learning in crises and normal situations.
\end{tabular}

\section{Introduction}

COVID-19 pandemic has caused severe effects in the field of education worldwide and it has led to the closure of schools, colleges and universities in almost all countries (Setiawan, 2020). All the schools and the majority of universities in Nepal have been locked down since March 2020 immediately after the outbreak of COVID-19 across the world including Nepal. Many schools and universities across the world have adopted the online mode of learning as soon as the lockdown was announced to prevent the spread of COVID-19 and keep people safe. Internet facilities have been considered as immediate alternative ideas to continue teaching and learning from home (Chick et al., 2020). However, only a few urban private schools and colleges, and a few departments at some universities have attempted to utilise freely available ICT apps such as Zoom, Teams, Google Meets, Facebook Messenger and Skype to teach their students from home. Moreover, we have observed that various social media such as YouTube, Twitter and Facebook have been worldwide popular among the new generation students who are highly engaged in the digital and social networks. Facebook, one of the most popular social networking websites, which allows users to share and exchange profiles, photos and videos with others, can be a useful tool in teaching various subjects including the English language (Srirat, 2014).

The use of Facebook for connecting with others and developing community relations and businesses has grown and become one of the key tools to create a brand (Shen \& Bissell, 2013). The use of information and communication technology (ICT) in education in developing countries has been argued that ICT fosters the 
quality of education, critical thinking skills and creativity, and broadens the economic scope in this global information society (Shields, 2011). The use of Facebook, an ICT tool in the learning process, has become a catalyst (Pimmer et al., 2012; Kabilan et al., 2010). Students can utilise Facebook in their learning of English, and teachers can integrate it as a meaningful educational tool. Facebook allows account holders to create social groups, participate in group interaction and share ideas with members (Bissessar, 2014). Likewise, a live video streaming platform provides users with an opportunity for sharing events and teaching contents (Rossetti, 2018).

The appropriate use of ICT can improve educational quality, foster critical thinking skills, expand access, increase financial sectors and facilitate inclusion in this expanding global information society (Shields, 2011). However, Rana and Rana (2020) argue that particularly government schools and universities without government funding and reliable source of income for the ICT project, having ICT illiterate teachers and administrative staff, and without ICT infrastructure cannot afford to adopt e-based learning. Although Nepal has a firm policy for the integration of ICT in education and focuses on the need for ICT to transform traditional pedagogies to modern learning to align with global practices, the lack of specific strategies for equipping schools with ICT infrastructure and teachers with ICT knowledge and skills will differ the expected implementation and achievement (Rana et al., 2020). For example, the National Curriculum Framework for School Education in Nepal 2007 has emphasised the use of ICT in classroom teaching, transforming traditional pedagogy to modern learning and improving the quality of education (Ministry of Education and Sports, 2007). The School Sector Reform Plan (SSRP) 2009-2015 is intended to improve the quality of education by equipping schools with ICT infrastructure and teachers with ICT knowledge and skills (Ministry of Education, 2009). Likewise, the Government of Nepal has developed the School Sector Development Plan (SSDP) 2016-2023 to equip students with ICT knowledge and skills so that they become ready as globally competitive citizens (Ministry of Education, 2016). In relation to teachers' pedagogical connection with ICT in the classroom, Rana et al. (2018) suggest that teachers need to be trained to use available ICT resources and gradually transform their traditional pedagogies to modern learning to achieve expected curriculum goals.

With the increasing use of the internet in personal and professional life in Nepal, the use of digital technology in education has promoted online modality as distance education and elevated its popularity. ICT is believed to be one of the key components for improving the quality of education in Nepal (Laudari \& Maher, 2019). Facebook, the most popular social networking site in Nepal, has become a means for communication, information and learning. While more than 2.6 billion people use Facebook across the world (Tankovska, 2021), Nepal had nearly 9.3 million Facebook users (33\% of the total population) in 2017 (Ministry of Communication and Information Technology, 2019). Where about $90.56 \%$ of the total population have access to the internet (Onlinekhabar, 2021), about 70\% of the total population use Facebook (Globalstats, 2022) for various purposes such as personal communication, business and education. The internet in the prolonged pandemic crisis has been realised as a fundamental need to adopt an alternative mode of teaching and learning. The present research, thus, aimed to answer three questions: How does Facebook Live help students learn English? How is basic school students' experience of learning the English language through Facebook Live streaming? And what specific strategies do they follow to learn communicative skills by watching Facebook Live? 


\section{Online and Distance Learning}

Web-based learning technologies have extensively expanded open, flexible, and distance educational environments (Rice et al., 2020). Some of the trends like fully online learning, blended and hybrid learning, open learning and Massive Open Online Courses (MOOCs) can be observed to understand how technology is changing the way the teachers teach (Bates, 2018). In his analysis of telemedicine in rural Nepal, Thapa (2011) explored how computer technology augmented educational and healthcare services in the Himalayas and identified various challenges such as low digital literacy, over-dependency on a focal actor, and poor physical infrastructure. In their study in India and Maldives, Thukral et al. (2012) investigated that online training was observed as a feasible and effective method of training for health professionals in acquiring knowledge and skills related to new-born care and that all the participants expressed satisfaction with content and delivery of the module. Similarly, a cross-sectional qualitative survey (Maré \& Mutezo, 2020) in South Africa showed that students were increasingly taking part in an online learning environment and the results showed a positive impact of e-tutoring on students' interaction and performance.

There can be various challenges for L2 (foreign and second language) instructors and material designers to plan and conduct online and distance learning (Reinhardt, 2020). Anderson and Dron (2011) earlier reported that technology can play a significant role to determine the potential pedagogies and provide learners with opportunities for developing their net presence. Qualitative research (Blackmon \& Major, 2012) in the USA explored that although students had a high level of satisfaction from online learning and courses, they still struggled to balance online courses and work responsibilities simultaneously. In their analysis of ICT use in higher education in Nepal, Rana and Rana (2020) reported that teachers' limited knowledge and skills of ICT prevented them and their students from effectively using the available ICT facilities in academic activities. In an analysis of informal online learning, Holland (2019) found that the use and design of interactive Web 2.0 platforms for informal learning which included MOOCs, community discussion boards, email lists, internet browser, digital learning objects, websites, blogs and Facebook in teaching and learning activities increased students' learning autonomy. Catalano (2014) suggested that using the principles of universal learning design can help develop distance education for all students including those with special needs. In the context of Nepal, Pangeni (2016) focused on digging out the contextual reality of open and distance learning (ODL) practices to develop and implement the online mode of learning. He suggested that the ODL as an option to the traditional model of education can complement the existing physical classroom pedagogies. However, Phirangee and Malec (2017) in a case study in Canada explored high dropout rates for some reasons such as the feeling of isolation and helplessness in their study. Laudari and Maher (2019) suggested incorporating ICT in teacher education to prepare qualified and skilful teachers.

\section{The Use of Facebook and its Affordances in Language Teaching and Learning}

Live streaming on various social networking websites such as Facebook, YouTube, Viber, Teams, Zoom, Meet and WhatsApp has become one of the great methods of teaching and learning among teachers and students (Hou et al., 2019). A study (Bridge et al., 2009) conducted on video streaming at Wayne State University in the USA 
investigated that medical students preparing their entrance test on live video streaming had similar results to the results of those who had normal classroom learning and further suggested offering students video streaming to support their learning styles. Similarly, research in Vietnam (Diep, 2019) reported that the teaching of English on live streaming using YouTube, Facebook, and many other live streaming platforms was a highly feasible and profitable business model in the Vietnamese market. Lu et al. (2018) in China revealed that both viewers and streamers desired deeper channels and live streaming gradually became popular means for various ideas. In their analysis of students' experiences of learning through live streaming, Wu and Gao (2020) reported that the growth of live video streaming technology provides educators and learners with new possibilities for transforming school education. A survey (Chen \& Lin, 2018) in Taiwan showed that approximately 65\% of Taiwanese people watch live streams via social network sites to get rid of stress and learn new ideas.

Facebook Live streaming offers real-time interaction such as comments and reactions including like, love, haha, wow, sad and angry and sociality (Haimson \& Tang, 2017). For example, English and Duncan-Howell (2008) earlier reported that the use of Facebook supported students during their teaching practicum and further suggested creating an online community of students for communication and collaboration. In addition, YouTube Live Streaming can be an effective tool for teaching and learning (Aniroh et al., 2018). Buzzetto-More (2015) investigated that the use of YouTube videos enhanced students' learning and understanding of course content by increasing their engagement in audio-visual materials. However, they argued that their attitude towards the use of digital technology was important in their learning activities.

\section{Strategies for Learning Communicative Skills}

Various strategies can help second language learners learn a new language (Ranjan \& Philominraj, 2020). For example, students' communicative skills can be improved by applying different activities such as an information gap, a jigsaw puzzle, games, problem-solving, and role-playing (Oradee, 2012). Zhu (2012) reported that students in China learnt English with the effective use of games and actively participated to develop their basic skills of listening and speaking. In their study in Ecuador, Toro et al. (2019) identified important strategies for developing learners' communicative competence such as the use of modelling, repetition, and pair and group work. Davis et al. (2018) in the Netherlands discovered cooperative learning, simulation and gaming, and interactive multimedia as three important strategies for active learning. Moreover, Şimşek and Direkci (2020) suggested that students playing digital games could learn English expressions in in-game communication.

Project-based learning can develop students' enthusiasm, confidence, creativity, and self-directed and collaborative learning ability in the online and distance mode of learning (Putri et al., 2017). The availability of technologies such as computers, free internet connections, language laboratories and memory devices play a significant role in developing teaching and learning activities and students' independent learning habits (Christine \& Ienneke, 2020). In addition, MOOCs can promote cooperation, direct engagement and open communication between learners, and help achieve learning goals of English communication and presentation skills (Yaşar, 2020). A case study (Arfae, 2020) in Iran emphasised that applying critical thinking skills would support foreign language learners' speaking skills. In their study in Spain, Ruiz de Azua et al. (2020) revealed 
that medical students who participated in social and communication training developed various skills such as empathy, active listening, social, interviewing and risk communication, and strategies to deal with complicated patients. Kawther (2020) in Iraq found that the application of an oral test for foreign language learners was observed as an effective means to assess their speaking activities and develop communicative strategies. However, Rana and Rana (2020) suggested that schools in Nepal need to adequately prepare their teachers and students to utilise ICT and to improve students’ listening and speaking skills.

\section{Method}

\section{Research Design: Participatory Action Research}

This study investigated the efficiency of Facebook Live streaming in teaching basic English communication to Basic School (Year 5 - 8) students in the COVID-19 pandemic. It as participatory action research (McIntyre, 2007) employed observation of self-managed Facebook Live streaming and semi-structured interview to gather qualitative information (Cohen et al., 2013). Documentary analysis (Fitzgerald, 2012) supported identifying research gaps and theoretical ideas to follow data analysis. The intervention design comprised the following processes: Planning of the materials, carrying out the actions, observation and collection of feedback, and reflections.

Planning: Following the lockdown of schools with the outbreak of the COVID-19 pandemic in Nepal in March 2020, Facebook Live was executed to teach basic English. The Facebook Live teaching, an alternative way of helping particularly Basic School students who were at home in absence of a physical classroom, was expected to engage students in learning activities. The live streaming was scheduled at noon and the notifications were circulated to students and parents on the Facebook wall on weekdays at 11:30 AM. In the beginning, the home quarantined students' problems were identified. Students did not get an opportunity to learn English because of the pandemic situation. To solve this identified problem, a plan of Fifty days of teaching English communication was designed with pre-recorded video lessons and live teaching materials. Basic School students and their parents were involved in this study.

Action: Execution of plan consisted of three strategies of going live on Facebook: broadcasting pre-recorded audio-visual record, live teaching and fusion of both. Initially, pre-recorded materials, which contained the voice of an English native speaker, were streamed on Facebook Live. Following the comments from students, live teaching was executed. Then, both pre-recorded audio-visual materials and live teaching were combined. Students started to watch live sessions with simple basic language functions such as greetings, thanking and requesting. It progressed through the grammatical structure and some more complex topics to get them to communicate effectively in English. Lives were broadcasted step-by-step on each topic and learners were given frequent opportunities for the practice of the lesson by pausing live teaching.

Observation: Following the teaching on Facebook Live, students' engagements were observed by following their participation and comments on Facebook Live, and their feedback was collected from their chat in the messenger group and the Zoom meeting which was organised after each week. 
Reflection: After each day of live teaching, the intervention activities were reflected on a daily diary which provided feedback to improve the following day live teaching on Facebook pages (School's Facebook page and researcher' personal Facebook account). The cycle of reflection continued throughout the entire intervention period (seven weeks). The daily reflection of live teaching on the pages helped improve daily teaching plans.

\section{Data Collection Procedure}

We involved 10 students (Year $5-8$ ) in this study based on their voluntary participation to gather their experiences of learning from Facebook Live streaming (Denzin \& Lincoln, 2017). Also, we interviewed each student's one parent (10 parents) to gather their responses to teaching through Facebook Live. Following the idea of Rana et al. (2018), the parents were approached through personal contact for the interviews who were observing their children's engagement on Facebook Live streaming. Students and parents were contacted on phones, Zoom, Facebook Messenger and Facebook page, and followed to obtain informed consent for interviews. Participants were interviewed by using Zoom, Facebook messenger and phone on multiple occasions and interviews were recorded on mobile devices and laptops. Students' participation and engagement in the live sessions were obtained from the Facebook pages. Also, screenshots helped capture important comments on the pages. An observational diary was made to follow a systematic analysis of data. The phenomenological approach as suggested by Creswell and Creswell (2017) provided an idea to explore a wide range of lived experiences of teaching English on Facebook Live and students' learning on the Facebook Live streaming. All the names used in this paper are pseudonyms.

\section{Thematic Analysis}

The data gathered through interviews and observations were analysed thematically based on the idea of Braun and Clarke (2006). Audio and video records of interviews were transcribed, organised into specific themes and interpreted descriptively. An inductive coding scheme helped identify themes from data, organise data into the themes and analyse data. Various archived documents such as journal articles, theses, books, website information, government documents and newspapers were read against the data gathered through interviews and observations.

\section{Findings}

The analysis of a wide range of qualitative information explored through the intervention study has informed about how the Facebook Live tool can be utilised to mitigate crises such as the COVID-19 pandemic and engage students in their learning from home in absence of normal physical classroom learning. Findings suggest that the pandemic situation not only challenged students and teachers but also provided them with an opportunity for learning new technology, learning English in a new way, developing independent skills and learning in collaboration with friends. 


\section{A New Way of Learning English}

Teaching on Facebook Live streaming has provided a new lens in distance learning which received significant appreciation from students who participated regularly. Live streaming was designed based on three strategies: broadcasting pre-recorded audio-visual material, live teaching, and the use of both strategies together. In the pre-recorded audio-visual material, lessons were designed to move from simple to complex language functions. The initial sessions were based on pre-recorded material that contained the voices of native English speakers Lessons focused on teaching language functions such as greetings, making requests, talking on the phone, going to the restaurant, and simple tense structure. Some of the students watching Facebook Live liked, commented, and shared the live sessions. Their comments indicated their enthusiasm for learning English through Facebook Live. For example:

This is great! I am very happy to watch Facebook live. I only used to go on Facebook lives for some events but now I am learning English speaking. I hope you will be broadcasting every day. (Amrit, student)

Amrit's comments indicated how a large number of students who were forced to stay home in the pandemic situation took the advantage of Facebook Live to learn English. Many similar comments on the Facebook page provided a kind of picture of how Facebook Live became an effective alternative way of learning English in the crisis. Both parents and students described Facebook Live as a new and innovative learning tool during the COVID-19 pandemic. For example:

Nowadays my son regularly watches Facebook Live broadcasts on the school page. I can notice some improvements in his English. He watches not only Facebook Live but also YouTube channel and TV and plays some online games. (Sukriti, parent)

I appreciate your brilliant idea of teaching English through Facebook Live. It is fruitful for my daughter. She is learning speaking skills. You can do great things. You can continue. (Krishna, parent)

These comments provided a much clearer picture of how Facebook Live streaming supported children's learning of English in absence of physical classroom learning. In the pandemic situation when students did not have other options for learning English, Facebook Live streaming, the first author initiated, engaged many students in English courses. For example, many students, who followed live teaching and recorded videos on personal as well as school's Facebook pages, shared those materials on their Facebook wall. Students' such activities energised us to improve live teaching. Live teaching without streaming pre-recorded materials received far more comments and likes from a significant number of more students. Students sent emojis such as "wow" and "like" during the live teaching.

It was observed that live teaching was more liked than live streaming video records. Therefore, both strategies were applied to reach the maximum number of viewers and to fulfil the participants' expectations. The fusion of video and live teaching increased the number of viewers. Facebook Live teaching increasingly gained popularity in the extended lockdown of schools. Not only students but also their family members viewed and shared the Facebook Live teaching on their personal Facebook wall. For example, Akash, a student, shared:

Now we are learning basic English through live streaming. All family members watch it at my home. It is very useful to learn pronunciation and conversation skills. 
His comments illustrate, Facebook Live, an effective ICT tool, can be used to teach English beyond the physical classroom. In particular, it can be utilised to create an online mode of learning to complement physical classroom learning. However, teachers need to have a systematic plan, and pedagogical as well as technological knowledge to effectively utilise the tool to teach English. A wise teacher can utilise immediate feedback on Facebook Live teaching from viewers in further planning and delivery of lessons on Facebook Live.

\section{Confidence in Speaking English}

Students shared the apathetic feeling they experienced in the beginning but they gradually started to like, comment and send emojis. Both live and recorded video streaming gradually increased their engagement. For example, Himal, a student, said:

I did not like to watch Facebook Live in the beginning but after some days of watching your Facebook Lives, it attracted me and learn more.

For many students, learning through Facebook Live was their first online learning experience. It, therefore, took some time to gain students' trust. In the second and following weeks, the number of students significantly increased. It indicated how Facebook Live became a new normal mode of learning English. Comments from many students inspired us to develop and present interactive lessons on Facebook Live. The participant students, for example, appreciated the interactive contents of the live teaching.

I learned to practise short conversations with you while you presented lessons. I feel free to practise with your activities. Because there is none around me, I do not have hesitation to practise English speaking. This is helpful to improve English. In the classroom, I feel shy to speak in front of others. We do not have that environment to practise English in school. (student)

Similar comments indicated how students practised English communication through Facebook Live and developed their confidence in speaking English. However, students shared their various issues such as weak mobile data and unreliable electricity that interrupted their smooth learning of English. In particular, these issues were reported by students from rural areas where they could use expensive mobile data but did not have broadband internet. It indicates, Facebook Live or similar online learning mechanisms would not be accessible for many students living in remote villages who have no smart device and internet. Besides, some students reported their engagement in online video games along with watching Facebook Live teaching of English. For example, Kumar, one of the students, said:

I do not like to watch Facebook Live regularly. I sometimes want to play online games like Freefire,

Ludo [...] and watch YouTube videos. I enjoy watching Facebook Live teaching and can learn some English but it is not always fun. Games and other videos can also help learn English.

In this situation, some parents suggested watching children's activities on their devices and facilitating their online learning.

I have no Wi-Fi connection and using data is not reliable in the village. While the connection is good, my daughter watches Facebook Lives and YouTube videos and play with mobile phones. (Amrita, parent) I have to monitor children. I have to see what they are doing. They pretend to watch Facebook Lives and take online classes but they misuse mobiles and play video games. (Puspa, parent) 
Teaching English through Facebook Live would have benefited those who consistently followed it and practised English lessons. Besides, students' attraction to online video games may pose a challenge, requiring parents to monitor them when they are learning English through Facebook Live. However, the increasing popularity of Facebook Live in absence of other options for learning in the crisis has provided a picture of how the online mode of learning can repair the educational void created by the lockdown in the pandemic situation.

\section{Development of Communicative Skills}

While streaming English lessons through Facebook Live during the pandemic situation, students were encouraged to develop their self-study habits. Their comments on the Facebook page and participation in live streaming indicated how it helped them engage in learning English. It was evident from interviews with the participants involved in this study that the new mechanism of teaching English through Facebook Live developed their independent learning skills while working at home. In the initial phase of Facebook Live streaming, the students involved in our interviews shared their experience of learning to use Facebook and then use it for coursework. For example, Pradip, a student of Grade Six, said:

I am learning some useful ideas using Facebook Lives. Like I comment and share things myself. I can upload and create pages and go to live streaming myself. I talk with friends and share the idea using a messenger group. I have created one closed group of my friends. I search for some links and applications myself at home. I can read and understand basic English. It is because of Facebook Live that has taught me some English. I can use simple English with my friends now.

His expression reflected the significant contribution of Facebook Live in students' learning of English communication. His comment indicated that live streaming enabled learners to develop their technological, as well as English communication skills. The interactive English lessons on Facebook Live that received maximum appreciation from students seem highly supportive in understanding English conversations and improving their speaking skills. Video streaming, for example, would have enabled them to explore how they could learn English without the teacher's direct presence. It was evident from interviews with students that they could comfortably reply to simple questions and follow general conversations in English. Their comments on the Facebook page indicated their progress in learning English. Especially, the live presentation of short conversations that consisted of three exchanges seemed a more effective strategy to develop students' communicative competence. Participant parents' responses indicated that the interactive model of presenting short conversation allowed students to learn both communicative and pronunciation skills. For example, Karma shared how his child was developing English speaking skills. He said:

I have a very good network connection at home and my daughter is learning English through Facebook Live. She starts classes herself. She can open Zoom for classes. She watches Facebook Live and online games and talks with her friends. She watches TV and YouTube videos and shares what she has learnt.

She is excited to learn using online resources. She has developed good digital skills and English herself without our supervision. She is developing her confidence in English speaking.

His comments indicated how students explored their ways to engage in online resources with increased digital proficiency and English competency. His idea implied that students were learning not only the English language but also the use of internet facilities available for them. Binod, one of the students, described his progress: 
I do some activities by using Google if there is any confusion. Google has become a good source for me. Likewise, teachers give me some links to explore and learn more. I open these links. I teach my parents to use different things like making pages and groups on Facebook.

His comment indicated that teaching English through Facebook Live would have reinforced students' English competency and their practice of digital technologies in learning activities. In addition, it was evident from the interviews that students were able to develop a comprehensive ability of English which enabled them to explore a wide range of English content on the internet. Not only oral but also comprehension skills were developed by the teaching of basic English through Facebook Live. Students' comments in English on live sessions indicated how Facebook Live sessions of English enabled them to develop communicative skills. For example, Pradip who was involved in this study started to share a story of about three minutes in English on Facebook Live. He sent me a note: "Sir, please watch my broadcasting live stories every day." His request indicated that students could use and develop some strategies for learning English through Facebook Live streaming. However, the first author's observations indicated that students learning English through live sessions can probably develop their comprehension ability, but they may still lack confidence in face-to-face communication.

\section{Gaining Language Competence through Collaborative Learning}

The students involved in this study used some Facebook functions such as comment, like, share and chat to communicate and collaborate among them. It was evident from observation of such activities on the Facebook page and interviews with them that their proactive engagement in discussions and conversations in groups seem effective for the development of English competence. For example, Sushil, a student, said:

I frequently comment on others' posts, share useful English videos and send some emojis such as care, happy and confused to my friends. I chat with my friends in Messenger about what we have learnt through Facebook Live.

His comments indicated that Facebook Live enabled many students to practise English speaking and develop conversation skills. It was evident from their comments and emojis on Facebook Live that students gained their confidence in using communicative English through their autonomous practice with the help of Facebook Live. For example, Dan, another student, said: "I use Messenger to talk to friends while watching Facebook Live teaching. I send the link through Messenger to invite them." This implies that along with learning English, a large number of students who regularly followed Facebook Live teaching were developing skills such as collaboration, interaction, group work and independent learning.

Notifications in Messenger groups, notice on the Facebook page and sharing of English lessons in Zoom meetings seemed effective strategies for enhancing students' learning of English. Students, for example, shared learning difficulties such as understanding native speakers' gestures and pronunciations while learning English lessons. For example, Amar wrote in Messenger group: "Binod, I could not understand pronunciation, did you understand it?" Similar questions and replies from several students suggested that students need to be engaged in interactivities to enable them to improve their English-speaking skills. Their discussions on the Facebook page and in the Messenger group provided feedback to the first author for the improvement of plans and delivery of lessons. For example, Karma, one of the parents involved in this study, said: 
Now my daughter practises English imitating teacher's speaking. The practice part on Facebook Live is very helpful for children to improve communicative skills. Lively video content and materials of English are simple and practical. Live sessions benefit school students a lot. They have the freedoms to practise without hesitation because there is none around them.

His comments indicated that English lessons on Facebook Live encouraged English language beginners to practise and get more exposure to English. In particular, the live sessions motivated students to apply the ideas in their practices and develop communicative skills. Students' collaborative activity indicated that they acquired both technological and content knowledge from the live sessions. It was found that social networking sites such as Facebook can be used to teach and learn English or other languages. However, it was evident from observations that the one-way delivery of English through Facebook Live may not be as productive as face-toface communications. It can, to some extent, enhance students' autonomous practice of English in the absence of teachers and friends.

\section{Discussion}

This study has identified that the Nepali students who were interviewed viewed Facebook Live as productive to learning English and other courses. They deemed such a learning tool as not only an essential technology of learning English but also as a means of an online learning community. They regarded it as an alternative mode of learning English from home in the absence of physical classroom learning. Studies (Rice et al., 2020; Wu \& Gao, 2020; Rana et al., 2021) have demonstrated that it is important for teachers to have technological, pedagogical and content knowledge to implement ICT tools in multicultural and heterogeneous classrooms. Holland (2019) stressed that the trend towards autonomous learning makes it important for teachers to incorporate the use of online learning tools as preparation for the $21^{\text {st }}$-century world. Bates (2018) argued that teachers need to be prepared for new pedagogical approaches and to understand how an online mode of learning can facilitate student learning.

In this study, it became evident from students' experiences of learning English through Facebook Live that the first author's strategies of teaching basic English allowed them to practise English speaking and develop some level of confidence in using conversational English. In absence of normal physical classroom learning in the pandemic situation, Facebook Live became an alternative mode of learning for many students. It resonates with the findings of Boberg et al. (2020) and Onat Kocabiyik (2021) in different contexts that Facebook as a social media can be used to disseminate lessons, discuss learning issues and share ideas to solve problems. For many students in this study, Facebook Live and page were the only means of learning English in the pandemic crisis.

Many of the students involved in this study appreciated that they were able to share learning experiences on Facebook pages and in Messenger groups following the ideas they observed on Facebook Live. Also, they regarded Facebook Live as an important means to acquire technological skills that they applied to search English videos on the internet, and as an assistive tool to develop communicative competence. Although research (Masserini \& Bini, 2021) showed dropout issues related to the use of Facebook in teaching and learning, the present study identified the increasing popularity of Facebook Live among students. However, 
findings suggest that the effectiveness of live streaming depends on how a teacher manages it for the specific purpose of teaching certain content. In addition, many teachers who are not trained to use ICT in instructional activities can encounter challenges to utilise the potentials of Facebook Live.

The participant students' comments indicated that English lessons on Facebook Live have played a significant role in developing their digital and English communication skills. Furthermore, for many students, it became an important tool to collaborate and communicate with many friends. Interaction with friends on the Facebook page as well as in Messenger groups improved their English. It was evident from comments on Facebook Live that students' English, albeit it had common grammatical errors, was comprehensible. However, some of the parents involved in this study reported that their children pretended to learn English on Facebook Live and played online video games. Parents' experiences of needing to watch children's learning suggest that it is essential for parents to support children's learning of English by providing an appropriate environment at home. Moreover, teachers need to develop practicable plans for teaching English and adopt more advanced ICT tools that have videoconference features to communicate with each other. Koehler et al. (2007) argued that teachers' technological, pedagogical and content knowledge is significant to choose and use potential ICT tools in their instructional activities. In particular, teachers' capability to integrate ICT into their instructional activities determines the effectiveness of online learning (Paudyal \& Rana, 2021). Studies (Davis et al., 2018; Yaşar, 2020) suggest that it is essential for students to have two-way communication to develop language skills. In the present study, however, it was not possible because Facebook Live does not have that feature. Instead, students created a closed group of friends on Messenger, which has a videoconferencing feature, to practise English and develop communicative skills. Facebook Live was used as a mainstream mode of getting ideas for learning English which was backed up by Messenger. The increasing participation of students on Facebook Live indicated its popularity as an educational tool (Barrot, 2018). Although the live streaming feature received positive comments from participants, the participants' attraction towards interactive features such as group chat and videoconference on Facebook was much higher than towards the live streaming feature.

Understanding the use of ICT tools and the ability to access them are interrelated. Both students and parents' comments suggested that, while students were willing to utilise the available digital devices and apps for learning, they initially had limited knowledge of how to use them and did not trust Facebook Live as an effective means of learning English. Rana and Rana (2019) argue that it is normal for many students, who do not have experience of using ICT tools and online learning, to have hesitation of learning through new ways. It might be argued that unless students in Nepal are enabled to use the latest ICT facilities, they may not develop confidence for using them for learning English or other languages. If students' attitude towards the use of ICT in their learning is negative, it can be a challenge that has to be overcome (Buzzetto-More, 2015). Nevertheless, students' access to digital devices and internet connectivity is an important issue. In this situation, Woelk and Whitefield (2020) argued that teachers' initiative to manage the online mode of learning cannot be as effective as in the international contexts where there is minimal ICT infrastructure. In this present study, students' responses indicated that many students did not have access to Facebook Live and could not join Messenger groups for learning English, and their schools could not initiate the online mode of learning either. It might be 
argued that, while many students did not have access to digital devices and internet connectivity, it was almost impossible for schools to shift from the physical classroom to the online learning environment.

\section{Conclusion}

The implementation of ICT in teaching and learning is a challenging job in Nepali schools. The first author identified several challenges such as students' access to digital devices and the internet, and limited digital skills that prevented them to access online education. Students expressed concerns about Facebook Live which did not allow them to have voice or video chat with teachers and friends. Although they appreciated Facebook Live as an effective ICT tool for teaching and learning English in the COVID-19 pandemic situation, some of them expressed their dissatisfaction that the English lessons on Facebook Live were oriented towards providing general ideas of speaking English rather than engaging learners in actual conversation as in the face-to-face situation. For many students involved in this study, however, learning to use ICT tools was essential. Nevertheless, understanding the way of speaking basic English was necessary to speak English in real life.

In Nepal, students are vulnerable as they have no guarantee of getting opportunities for using ICT in their learning activities in schools. Findings suggest that the majority of students, especially from community schools, cannot adopt the online mode of learning. Because most students particularly in the rural areas do not have access to digital devices and the internet, schools cannot implement e-based learning. Although the parents and students involved in this study appreciated the first author's initiative of teaching English through Facebook Live, they were worried because many students who did not have access to digital devices and the internet could only wait for the notice from their schools to resume physical classes. Nevertheless, the first author's experiences of needing and wanting to develop a more advanced online mode of learning suggest that Facebook Live, albeit it became the only option for many students in the pandemic situation, need to be associated with other advanced apps such as Microsoft Teams, Zoom and Skype to allow both teachers and students to have two-way live communication and improve communicative skills. Nevertheless, parents expressed concerns that their children who pretended to watch Facebook Live for learning English sneaked to online video games. However, teaching English through Facebook Live engaged many students in learning activities.

The findings of this study based on the limited number of students and their parents' experiences of one teacher's attempt to teach English through Facebook Live does not offer a generalizable portrayal of the practices of many teachers in Nepal. However, the evidence that was identified in this study indicates directions that can be explored in future studies. This study informs that while the government and educational institutions emphasised the online mode of learning to complement the traditional physical classroom learning in the pandemic situation, there are challenges for countries like Nepal attempting to operate international practices of education.

\section{Acknowledgements}

We would like to acknowledge the valuable information and time of the participants involved in this study. 


\section{References}

Anderson, T., \& Dron, J. (2011). Three generations of distance education pedagogy. International Review of Research in Open and Distributed Learning, 12(3), 80-97. https://doi.org/10.19173/irrodl.v12i3.890

Aniroh, K., Latifah, H., \& Ariyanto, A. A. G. (2018). The effectiveness of youtube live streaming as digital learning media in tourism and guiding subject. Arab World English Journal Special Issue on CALL, 4(4). https://doi.org/10.2139/ssrn.3226700

Arfae, A. M. (2020). The impact of teaching critical thinking on EFL learners' speaking skill: A case study of an Iranian context. English Language Teaching, 13(1), 112-123. https://doi.org/10.5539/elt.v13n1p112

Barrot, J. S. (2018). Facebook as a learning environment for language teaching and learning: A critical analysis of the literature from 2010 to 2017. Journal of Computer Assisted Learning, 34(6), 863-875. https://doi.org/https://doi.org/10.1111/jcal.12295

Bates, A. W. (2018). Teaching in a digital age: Guidelines for designing teaching and learning. Open Educational Resources Collection.

https://irl.umsl.edu/oer/6?utm_source=irl.umsl.edu\%2Foer\%2F6\&utm_medium=PDF\&utm_campaign=P DFCoverPages

Bissessar, C. S. (2014). Facebook as an informal teacher professional development tool. Australian Journal of Teacher Education, 39(2), 9. https://doi.org/10.14221/ajte.2014v39n2.9

Blackmon, S. J., \& Major, C. (2012). Student experiences in online courses: A qualitative research synthesis. The Quarterly Review of Distance Education, 13(2). https://www.cu.edu/doc/student-experiences-onlineclassesqual-study.pdf

Boberg, S., Quandt, T., Schatto-Eckrodt, T., \& Frischlich, L. (2020). Pandemic populism: Facebook pages of alternative news media and the corona crisis--A computational content analysis. Muenster Online Research (MOR) Working Paper. https://arxiv.org/

Braun, V., \& Clarke, V. (2006). Using thematic analysis in psychology. Qualitative Research in Psychology, 3(2), 77-101. https://doi.org/10.1191/1478088706qp063oa

Bridge, P. D., Jackson, M., \& Robinson, L. (2009). The effectiveness of streaming video on medical student learning: a case study. Medical Education Online, 14(1), 4506. https://doi.org/10.3402/meo.v14i.4506

Buzzetto-More, N. (2015). Student attitudes towards the integration of YouTube in online, hybrid, and webassisted courses: An examination of the impact of course modality on perception. Journal of Online Learning and Teaching, 11(1), 55-73. https://jolt.merlot.org/vol11no1/Buzzetto-More_0315.pdf

Catalano, A. (2014). Improving distance education for students with special needs: A qualitative study of students' experiences with an online library research course. Journal of Library Information Services in Distance Learning, 8(1-2), 17-31. https://doi.org/10.1080/1533290X.2014.902416

Chen, C.-C., \& Lin, Y.-C. (2018). What drives live-stream usage intention? The perspectives of flow, entertainment, social interaction, and endorsement. Telematics Informatics, 35(1), 293-303. https://doi.org/10.1016/j.tele.2017.12.003

Chick, R. C., Clifton, G. T., Peace, K. M., Propper, B. W., Hale, D. F., Alseidi, A. A., \& Vreeland, T. (2020). Using technology to maintain the education of residents during the COVID-19 pandemic. Journal of Surgical Education, 77(4). https://doi.org/10.1016/j.jsurg.2020.03.018 
Christine, P., \& Ienneke, I. D. (2020). Enhancing The post-millennial students using information communication and technology in learning English. Journal of Physics: Conference Series, 1477, 042029. https://doi.org/10.1088/1742-6596/1477/4/042029

Cohen, L., Manion, L., \& Morrison, K. (2013). Research methods in education. Routledge.

Creswell, J. W., \& Creswell, J. D. (2017). Research design: Qualitative, quantitative, and mixed methods approaches. Sage publications.

Davis, D., Chen, G., Hauff, C., \& Houben, G.-J. (2018). Activating learning at scale: A review of innovations in online learning strategies. Computers \& Education, 125, 327-344. https://doi.org/10.1016/j.compedu.2018.05.019

Denzin, N. K., \& Lincoln, Y. S. (2017). The SAGE handbook of qualitative research. SAGE Publications.

Diep, T. H. (2019). Live streaming as a business model for teaching English in Vietnam [Bachelors thesis, Lahti University of Applied Sciences]. Vietnam. http://urn.fi/URN:NBN:fi:amk-201904014075

English, R. M., \& Duncan-Howell, J. (2008). Facebook $\bigodot$ goes to college: Using social networking tools to support students undertaking teaching practicum. Journal of Online Learning Teaching, 4(4), 596-601.

Fitzgerald, T. (2012). Documents and documentary analysis. In A. R. J. Briggs, M. Coleman, \& M. Morrison (Eds.), Research methods in educational leadership management (3 ed., pp. 296-308). Sage.

Globalstats. (2022). Social media stats Nepal [Dec 2020 - Dec 2021]. https://gs.statcounter.com/social-mediastats/all/nepal

Haimson, O. L., \& Tang, J. C. (2017). What makes live events engaging on Facebook Live, Periscope, and Snapchat. Proceedings of the 2017 CHI conference on human factors in computing systems, https://doi.org/10.1145/3025453.3025642

Holland, A. A. (2019). Effective principles of informal online learning design: A theory-building metasynthesis of qualitative research. Computers \& Education, 128, 214-226. https://doi.org/10.1016/j.compedu.2018.09.026

Hou, F., Guan, Z., Li, B., \& Chong, A. Y. L. (2019). Factors influencing people's continuous watching intention and consumption intention in live streaming. Internet Research, 30(1). https://doi.org/10.1108/INTR-042018-0177

Kabilan, M. K., Ahmad, N., \& Abidin, M. J. Z. (2010). Facebook: An online environment for learning of English in institutions of higher education? The Internet Higher Education, 13(4), 179-187. https://doi.org/10.1016/j.iheduc.2010.07.003

Kawther, P. S. (2020). English language learners' attitudes toward the effectiveness of communicative strategies to develop their speaking skill. Journal of Tikrit University for the Humanities, 27(1), 1-19. https://doi.org/10.25130/jtuh.27.2020.1

Koehler, M. J., Mishra, P., \& Yahya, K. (2007). Tracing the development of teacher knowledge in a design seminar: Integrating content, pedagogy and technology. Computers \& Education, 49(3), 740-762. https://doi.org/10.1016/j.compedu.2005.11.012

Laudari, S., \& Maher, D. (2019). Barriers to ICT use in EFL teacher education courses in Nepal: An activity theory perspective. Journal of NELTA, 24(1-2), 77-94. https://doi.org/10.3126/nelta.v24i1-2.27681

Lu, Z., Xia, H., Heo, S., \& Wigdor, D. (2018). You watch, you give, and you engage: A study of live streaming practices in China. Proceedings of the 2018 CHI Conference on Human Factors in Computing Systems, 
Montreal QC, Canada. https://doi.org/10.1145/3173574.3174040

Maré, S., \& Mutezo, A. T. (2020). The effectiveness of e-tutoring in an open and distance e-learning environment: evidence from the University of South Africa. Open Learning: The Journal of Open, Distance and e-Learning, 36(2), 164-180. https://doi.org/10.1080/02680513.2020.1717941

Masserini, L., \& Bini, M. (2021). Does joining social media groups help to reduce students' dropout within the first university year? Socio-Economic Planning Sciences, $\quad 73, \quad 100865$. https://doi.org/10.1016/j.seps.2020.100865

McIntyre, A. (2007). Participatory action research (Vol. 52). Sage Publications.

Ministry of Communication and Information Technology. (2019). 2019 Digital Nepal Framework. Ministry of Communication and Information Technology.

https:/mocit.gov.np/application/resources/admin/uploads/source/EConsultation/EN\%20Digital\%20Nepa 1\%20Framework\%20V8.4\%2015\%20July\%20\%202019.pdf

Ministry of Education and Sports. (2007). National Curriculum Framework for School Education in Nepal, Curriculum Development Centre, Ministry of Education and Sports. http://moe.gov.np/assets/uploads/files/National-Curriculum-Framework-2007-English.pdf

Ministry of Education. (2009). School Sector Reform Plan (2009-2015). Ministry of Education, Government of Nepal. http://www.moe.gov.np/assets/uploads/files/SSRP_English.pdf

Ministry of Education. (2016). School Sector Development Plan 2016-2023. Ministry of Education, Government of Nepal.

http://www.moe.gov.np/assets/uploads/files/School_Sector_Development_Plan.pdf

Onat Kocabiyık, O. (2021). Social media usage experiences of young adults during the COVID 19 pandemic through social cognitive approach to uses and gratifications. International Journal of Technology in Education and Science, 5(3), 447-462. https://doi.org/10.46328/ijtes.226

Onlinekhabar. (2021). The number of internet users in Nepal up by 5.8 million in 1 year. Onlinekhabar. https://english.onlinekhabar.com/the-number-of-internet-users-in-nepal-up-by-5-8-million-in-1-year.html

Oradee, T. (2012). Developing speaking skills using three communicative activities (discussion, problemsolving, and role-playing). International Journal of Social Science Humanity, 2(6), 533. https://doi.org/10.7763/IJSSH.2012.V2.164

Pangeni, S. K. (2016). Open and distance learning: Cultural practices in Nepal. European Journal of Open, Distance and E-learning, 19(2), 32-45. https://oi.org/10.1515/eurodl-2016-0006

Paudyal, G. R., \& Rana, K. (2021). How university lecturers and students interpret opportunities and challenges of online mode of learning. International Journal of Research in Education and Science (IJRES), 7(4), 1006-1022. https://doi.org/10.46328/ijres.2383

Phirangee, K., \& Malec, A. (2017). Othering in online learning: An examination of social presence, identity, and sense of community. Distance Education, 38(2), 160-172.

Pimmer, C., Linxen, S., \& Gröhbiel, U. (2012). Facebook as a learning tool? A case study on the appropriation of social network sites from mobile phones in developing countries. British Journal of Educational Technology, 43(5), 726-738. https://doi.org/10.1111/j.1467-8535.2012.01351.x

Putri, N. L. P. N. S., Artini, L. P., \& Nitiasih, P. K. (2017). Project-based learning activities and EFL students' productive skills in English. Journal of Language Teaching Research, 8(6), 1147-1155. 
Rana, K., \& Rana, K. (2019). Teaching and testing of English listening and speaking in secondary schools in Nepal: Pretend for praxis? Journal of NELTA, 24(1-2), 17-32. https://doi.org/10.3126/nelta.v24i12.27678

Rana, K., \& Rana, K. (2020). ICT integration in teaching and learning activities in higher education: A case study of Nepal's teacher education. Malaysian Online Journal of Educational Technology, 8(1), 36-47. https://doi.org/10.17220/mojet.2020.01.003

Rana, K., Greenwood, J., \& Fox- Turnbull, W. (2019). Implementation of Nepal's education policy in ICT: Examining current practice through an ecological model. The Electronic Journal of Information Systems in Developing Countries, 86(2), e12118. https://doi.org/10.1002/isd2.12118

Rana, K., Greenwood, J., \& Henderson, R. (2021). Teachers' experiences of ICT training in Nepal: How teachers in rural primary schools learn and make progress in their ability to use ICT in classrooms. Technology, Pedagogy and Education. https://doi.org/10.1080/1475939X.2021.2014947

Rana, K., Greenwood, J., Fox-Turnbull, W., \& Wise, S. (2018). A shift from traditional pedagogy in Nepali Rural Primary Schools? Rural teachers' capacity to reflect ICT policy in their practice. International Journal of Education and Development using Information and Communication Technology, 14(3), 149166. http://ijedict.dec.uwi.edu/viewarticle.php?id=2521

Rana, K., Greenwood, J., Fox-Turnbull, W., \& Wise, S. (2019). Challenges in accessing fieldwork in rural Himalayas: An emerging researcher's experiences. Waikato Journal of Education, 24(1), 67-77. https://doi.org/10.15663/wje.v24i1.605

Ranjan, R., \& Philominraj, A. (2020). Language learning strategies, motivation and gender in foreign language context. Universal Journal of Educational Research, 8(2), 591-604. https://doi.org/10.13189/ujer.2020.080231

Reinhardt, J. (2020). Metaphors for social media- enhanced foreign language teaching and learning. Foreign Language Annals, 53(2). https://doi.org/10.1111/flan.12462

Rice, M. F., Lowenthal, P. R., \& Woodley, X. (2020). Distance education across critical theoretical landscapes: touchstones for quality research and teaching. Distance Education, 41(3), 319-325. https://doi.org/10.1080/01587919.2020.1790091

Rossetti, G. (2018). Matteo Salvini and the potentials of Facebook live-stream. http://mastersofmedia.hum.uva.nl/blog/2018/09/24/matteo-salvini-and-the-potentials-of-facebook-livestream/

Ruiz de Azua, S., Ozamiz-Etxebarria, N., Ortiz-Jauregui, M. A., \& Gonzalez-Pinto, A. (2020). Communicative and social skills among medical students in Spain: a descriptive analysis. International Journal of Environmental Research Public Health, 17(4), 1408. https://doi.org/10.3390/ijerph17041408

Setiawan, A. R. (2020). Scientific literacy worksheets for distance learning in the topic of coronavirus 2019 (COVID-19). EdArXiv. https://doi.org/10.35542/osf. io/swjmk

Shen, B., \& Bissell, K. (2013). Social media, social me: A content analysis of beauty companies' use of Facebook in marketing and branding. 19(5), 629-651. https://doi.org/10.1080/10496491.2013.829160

Shields, R. (2011). ICT or I see tea? Modernity, technology and education in Nepal. Globalisation, Societies and Education, 9(1), 85-97. https://doi.org/10.1080/14767724.2010.513536

Şimşek, B., \& Direkci, B. (2020). In-game language usages of students playing online games: The sample of 
League of Legends. Elementary Education Online, 19(4), 2042-2052. https://doi.org/10.17051/ilkonline.2020.763315

Srirat, K. (2014). Using Facebook group to facilitate teaching English for everyday communication. The 2014 WEI International Academic Conference Proceedings. The West East Institute, Budapest, Hungary. http://www.westeastinstitute.com/wp-content/uploads/2014/07/Kesinee-Srirat-Full-Paper.pdf

Tankovska, H. (2021). Countries with the most Facebook users 2020 https://www.statista.com/statistics/268136/top-15-countries-based-on-number-of-facebook-users/

Thapa, D. (2011). The role of ICT actors and networks in development: The case study of a wireless project in Nepal. The Electronic Journal of Information Systems in Developing Countries, 49(1), 1-16. https://doi.org/10.1002/j.1681-4835.2011.tb00345.x

Thukral, A., Sasi, A., Chawla, D., Datta, P., Wahid, S., Rao, S., Kannan, V., Veeragandam, A., Murki, S., \& Deorari, A. K. (2012). Online neonatal training and orientation programme in India (ONTOP-IN) - the way forward for distance education in developing countries. Journal of Tropical Pediatrics, 58(6), 486490. https://doi.org/10.1093/tropej/fms029

Toro, V., Camacho-Minuche, G., Pinza-Tapia, E., \& Paredes, F. (2019). The use of the communicative language teaching approach to improve students' oral skills. English Language Teaching, 12(1), 110-118. https://doi.org/10.5539/elt.v12n1p110

Woelk, K., \& Whitefield, P. D. (2020). As close as it might get to the real lab experience-live-streamed laboratory activities. Journal of Chemical Education, 97(9), 2996-3001. https://doi.org/10.1021/acs.jchemed.0c00695

Wu, M., \& Gao, Q. (2020). Using live video streaming in online tutoring: Exploring factors affecting social interaction. International Journal of Human-Computer Interaction, 36(10), 964-977. https://doi.org/10.1080/10447318.2019.1706288

Yaşar, M. Ö. (2020). Can MOOCs Promote EFL learners' English communication skills? Language Technology, 2(1), 1-15. https://dergipark.org.tr/en/pub/lantec/issue/52176/659394

Zhu, D. (2012). Using games to improve students' communicative ability. Journal of Language Teaching Research, 3(4). https://doi.org/10.4304/j1tr.3.4.801-805

\section{Author Information}

\section{Prakash Chandra Giri}

(iD) https://orcid.org/0000-0002-9610-5290

Faculty of Social Sciences and Education

Nepal Open University, Lalitpur

Nepal

\section{Karna Rana}

(iD) https://orcid.org/0000-0003-3665-878X

Faculty of Social Sciences and Education

Nepal Open University, Lalitpur

Nepal

Contact e-mail: karnabdr@gmail.com 